\title{
Johnson on Novelty and Originality
}

\section{Citation}

Engell, James. 1978. Johnson on novelty and originality. Modern Philology 75(3): 273-279.

\section{Published Version}

http://dx.doi.org/10.1086/390791

\section{Permanent link}

http://nrs.harvard.edu/urn-3:HUL.InstRepos:3355448

\section{Terms of Use}

This article was downloaded from Harvard University's DASH repository, and is made available under the terms and conditions applicable to Other Posted Material, as set forth at http:// nrs.harvard.edu/urn-3:HUL.InstRepos:dash.current.terms-of-use\#LAA

\section{Share Your Story}

The Harvard community has made this article openly available.

Please share how this access benefits you. Submit a story.

\section{Accessibility}




\section{Johnson on Novelty and Originality}

\section{James Engell}

Johnson felt surprised to find Edward Young, in Conjectures on Original Composition, "receive as novelties what he thought very common maxims." $1 \mathrm{He}$ was taking it for granted that most readers want to be pleased quickly ${ }^{2}$ and naturally favor those works which present a new or unusual aspect. But he also recognized that only a thin line separates pleasantly familiar accounts from hackneyed ones and concluded that good writing is fresh; that is, it challenges our willingness to believe without itself degenerating into something unbelievable.

The first requirement of a writer, if he is to have a chance to display other virtues, is to capture and hold interest. Johnson praises Dryden's Aeneid because it allures, then keeps thoughts in "pleasing captivity" $(1: 454)$. But Prior's 2,500-line Solomon, though considerably shorter, drags in comparison. The story lacks developed characters and action. Its conclusion is never in doubt and infects the poem with tediousness, "the most fatal of all faults" $(2: 206)$, fatal especially when it occurs in long imaginative works. We may read to the end of a boring lyric or sonnet, but only because it is so brief. Shorter works should excite, sharpen, and intensify perception or reflection. Johnson summarizes his dislike of Gray's Prospect of Eton College with the terse verdict that it "suggests nothing to Gray which every beholder does not equally think and feel" $(3: 434)$. The key word here is "equally," for Johnson does not object so much to the poem's commonly felt nostalgia and sense of lost youth as he does to the mundane quality of Gray's expression. We cannot ask of poets that they give us nothing but new thoughts, morals, or ideas; for, even assuming they could, such totally unfamiliar brilliance would put them out of touch with nearly all readers. But, on the other hand, it seems natural to look at poetry-at writing in generalfor new images and stories, fresh and magnetic language, or an unprecedented arrangement of parts, any one of which can restore lively force to "unoriginal" conceptions and "ancient" wisdom. It is a bonus if the poet also communicates genuinely new thought or observations. Writers must forever be escaping the conventions they have created. This is the essence of Rambler 154, where Johnson says, "Whatever hopes for the veneration of mankind must have invention in the design or the execution; either the effect itself must be new or the means by which it is produced.... That which hopes to resist the blast of malignity, and stand firm against the attacks of time, must contain in itself some original principle of growth" $(5: 59)$.

1/James Boswell, Boswell's Life of Johnson, ed. George Birkbeck Hill, rev. L. F. Powell, 2d ed., 6 vols. (London, 1950), 5:269. The central importance of novelty and originality in Johnson's criticism is stressed by W. R. Keast ("The Theoretical Foundations of Johnson's Criticism," in Critics and Criticism: Ancient and Modern, ed. R. S. Crane [Chicago, 1952]), Jean H. Hagstrum (Samuel Johnson's Literary Criticism [Minneapolis, 1952], esp. pp. 158-65, 169, 173, 179), and W. J. Bate (The Achievement of Samuel Johnson [New York, 1955], pp. 189-93). See also, for briefer discussion, R. D. Stock, Samuel Johnson and Neoclassical Dramatic Theory (Lincoln, Nebr., 1973), pp. 167-68.

2/Samuel Johnson, "Cowley," in Lives of the English Poets, ed. George Birkbeck Hill, 3 vols (Oxford, 1905), 1:59. Subsequent references to the Lives are cited in the text by volume and page number. References to other works by Johnson, also cited parenthetically, are to the Yale Edition of the Works (New Haven, Conn., 1958-). 
But Johnson characteristically presses both sides of a question and points out that time can be a writer's ally as well as his opponent. Changes in common language, speech, manners, and attitudes supply new material. Representing unique characteristics of a period or population fulfills the mimetic function of art to some degree. "The manufacturers of literature" can at least provide every society with a description of itself (Rambler 145 [5:7-12]). In other words, partand a reliable, attractive part-of what an author must do to make himself "original" is already being done for him. He has only to record the changes outside himself rather than try to concoct them from his own imagination. "The mutability of mankind will always furnish writers with new images" (Adventurer 95 [2:429]). From this general premise Johnson draws the corollary that imitations of classical authors improve when writers employ images and activities not available to their predecessors. Cowley's Latin poems surpass Milton's because Cowley used images and objects unknown to Roman poets ("Cowley," $1: 13) .^{3}$

Although this kind of variation helps every writer to attract followers, it cannot, in the end, serve as a substitute for new plots or for new ideas with their corresponding images. (Johnson, believing like Locke that ideas exist through their representative images, often uses "image" to encompass simile, metaphor, sensory description, and intellection.) No major critic in the whole classical tradition is quicker to object to the routine copying of language, myths, or stock devices from previous writers. While "diversifying the surface of knowledge, and luring the mind by a new appearance to a second view" has real value (Adventurer 137 [2:491]), mere variation is forced to obey the law of diminishing returns. Readers may initially be duped by refinements and mistake them for firsthand works, but if they read at all extensively, they will soon feel either bored or cheated. There is a side of Johnson that never forgets that literature is a sort of business serving the human imagination, in which the motive for buying or reading is much the same as in any other enterprise (fatigue with what is old and a wish for new diversion). We see this in his readiness to attack works that have exhausted their literary currency. His pet example is the pastoral. It has been drained by imitators who transmit "the same images in the same combination from one to another, till he that reads the title of a poem, may guess at the whole series of the composition" (Rambler 36 [3:197]; see also no. 37).

If great writers of the past did imitate, they transformed or enlarged their models almost out of recognition (see ibid., no. 145). Virgil's emulation of Theocritus does not bother Johnson because, first, Virgil had the advantage of another language and, second, "obtains his superiority [over the Sicilian and his other imitators] by deviating from the pastoral character, and performing what Theocritus never attempted" (Adventurer 92 [2:418]), that is, by indirectly recounting real personal events and their accompanying sentiments. Pope's Dunciad expanded Dryden's MacFlecknoe so much "as justly to claim the praise of an original" ("Pope," $3: 241$ ). This kind of imitation-in which a great mind

3/But see Douglas Bush, ed., A Variorum Commentary on the Poems of John Milton, 7 vols. (New York, 1970), 1:3-21. 
taps the suggestiveness and potential it discovers in an original and then uses these as starting blocks rather than as constant references-can, says Johnson, "almost compensate for invention" (Rambler 143 [4:401]).

The easiest (and therefore the most tempting) device to insure immediate pleasure is "novelty," regardless of its fidelity to how objects appear and people really act. This can be dangerous, especially to the moralist, whose first obligation is to convey a truth that can never be "novel" and which has therefore already grown limp in clichés and aphorisms. But because "novelty is the great source of pleasure" ("Prior," 2:206), writers are inevitably tempted to try to be new by any means. Johnson describes this urge to be completely different when he speaks of "the seduction," "the allurement," or "the pomp of novelty." Novelties without fidelity to experience easily make an impression on any mind (see Rambler 78), but, like most things too easily obtained for their own sake, their attraction soon fades, and the distortions of the "unnatural" are discarded even sooner than purely conventionalized forms (ibid., no. 4). On this premise Johnson attacked what he considered the difficult, esoteric nature of Gray's odes. Of The Bard, based on legend and filled with historical allusions Gray refused to footnote, Johnson remarked, "To select a singular event, and swell it to a giant's bulk by fabulous appendages of spectres and predictions, has little difficulty, for he that forsakes the probable may always find the marvelous. And it has little use: we are affected only as we believe" ("Gray," 3:438). In short, a rare or exotic event has no intrinsic advantage as a subject, if only because, after the first impression, the reader begins to ask what use it serves (Rambler 78).

Johnson doubted that either The Splendid Shilling or Tristram Shandy would be long remembered. He was wrong in his prediction about the latter (and it is reassuring to realize how even great critics can fail to predict or dictate taste completely). But if he underestimated the appeal of Sterne's novel to each new generation, perhaps it was because the book came to have affinities with modern fiction that eventually made it seem not strange but actually closer, more familiar to readers. Yet Johnson also recognized that some works survive long periods and remain unique. They ward off imitators because an imitation would carry the oddity one step too far. Butler's Hudibras is an example, for "when it is no longer strange, we perceive its deformity. It is a kind of artifice, which by frequent repetition distorts life" ("Butler," $1: 218$ ).

Novelty harbors another danger. An author who has tried to rest his reputation on it is forced to keep it up, going to bizarre extremes, where "how much soever is given, there must always be reason to imagine that more remains" (Rambler 207 [5:314]). But when a desire of novelty does not "violate essential principles," when a writer keeps a faithful eye on objective reality, he introduces what is new to real advantage. This "grace of novelty" ("Milton," $1: 146$ ) means fresh and natural qualities are fused. As Jean Hagstrum remarks, "a union of familiarity and novelty" is for Johnson "the very core of his theory of literary pleasure"; and this union "is perhaps his most basic aesthetic requirement." 4 Thomson's popular Seasons teaches a new way of looking at landscape; vistas 
and details merge in unusual but acute, accurate descriptions. The Seasons has no model, but "the reader . . . wonders that he never saw before what Thomson shews him, and that he never has felt what Thomson impresses" (3:299). Johnson liked the ships' cannon battle in Dryden's Annus Mirabilis because it showed that a poet could successfully appropriate what was not already poetic tradition by using his eyes to observe as well as to read. ${ }^{5}$ Most poets, in Johnson's opinion, "borrow every thing from their predecessors, and commonly derive very little from nature or from life" ("Dryden," 1:430). It is typical of Johnson that he praised Dryden's adventuresomeness in including the cannon battle but not what Dryden himself made sure to mention about many lines in the poem, that they were imitations (often very nearly translations) of Virgil.

If genres like the pastoral lose vitality in the same way set images and descriptions do, Johnson saw that new genres must and could replace the old. He sensed that, if one area of literary endeavor is eliminated, immediately the vacuum cries out for something novel to fill it. In this vein he proposed Gay's ballad-opera, a new form that rapidly came into demand ("Gay," 2:282-83), as the kind of production that could prevent fossilization of form.

Novelty fused with truth, "the basis of all excellence" ("Cowley," 1:6), yields the long-wearing alloy of originality, an idea Johnson connects with invention, imagination, and genius. Accordingly, as W. R. Keast says, works for Johnson "succeed or fail-are excellent or poor-to the extent that they satisfy the general conditions of pleasure, namely, truth and novelty." ${ }_{6}^{6}$ In his overriding concern for art as fundamentally an imitation of objective reality, he makes originality itself dependent on study and experience, on an earned, direct knowledge of life and manners, not on a literary education. The originality of an author whose eyes transmit images of external reality to himself earns "merit of the highest kind" ("Congreve," 2:228).

Originality comes into play most importantly when it concerns "invention," because "the essence of poetry is invention; such invention as, by producing something unexpected, surprises, and delights" ("Waller," 1:291). "Invention" here loosely refers to the whole creative process, by which in poetry "new trains of events are formed and new scenes of imagery are displayed" ("Pope," $3: 247$ ). But this creativity, what in "Milton" Johnson calls "the highest praise of genius," is most valuable when it produces new plots, new events and actions, for these act as divining rods leading to fresh characters, images, and language.

Among the powers that must conduce to constitute a poet, the first and most valuable is invention; and of all the degrees of invention, the highest seems to be that which is able to produce a series of events . . . to strike out the first hints of a new fable; hence to introduce a set of characters so diversified in their several passions and interests, that from the clashing of this variety may result many necessary incidents; to make these incidents surprizing, and yet natural, so as to delight the imagination without shocking

5/Johnson had in mind stanzas like no. 188:

The distance judg'd for shot of every size,

The Linstocks touch, the pond'rous ball expires:

The vig'rous Sea-man every port-hole plies,

6/Keast, p. 399.

And adds his heart to every Gun he fires. 
the judgement of a reader; and finally to wind up the whole in a pleasing catastrophe, produced by the very means which seem most likely to oppose and prevent it, is the utmost effort of the human mind. [Dedication to Shakespeare Illustrated, written for Mrs. Lennox, 7:48-49]

In his own Preface to Shakespeare Johnson stresses the "progress of his fable." He finds the seemingly unborrowed plot of The Tempest Shakespeare's most original and fascinating and in his last note to that play emphasizes that the poet made his plot "instrumental to the production of many characters, diversified with boundless invention" (7:135). Johnson presents a critical view essentially based on the Aristotelian and generally classical concern with action-human motives, desires, and events - but one also flexible enough to include the increasing modern emphasis on character and particular image. And of course a writer's originality need not appear only in his plots. In his restive search for the "original," Johnson is quick to notice that Cooper's Hill introduced "local poetry." As such it gives Denham "the rank and dignity of an original author" (1:77-78). Congreve's originality rests in his wit and conceits, in thrusts and parries of dialogue $(2: 228)$. Thomson's style, his pauses, diction, and rhythm are at once new and musical. Unlike others, he did not merely ape Milton's mannerisms but extended the use of Miltonic blank verse in an "original" way. Into this varied compass of what can be called "original" Johnson also admits the supernatural creations in The Rape of the Lock because in that poem they enjoyed "their first poetical existence" ("Pope," 3:233).

"Originality," as distinct from mere "novelty," implies the presence of other values in and through which the origination is working. The concept especially contrasts with stock notions of the time concerning the "original genius" who spontaneously creates $a b$ intra. Genius requires study, observation, and a willingness to learn "what only experience can bestow" (Idler 25 [2:79]). In "Milton" Johnson pleads for the acquisition of knowledge augmented by an active sense of the present. Imaginations dwelling exclusively in either past or present will fail in both fiction and morality (see Rambler 4 [3:19-20]). In other words, a good author is not singly endowed but has numerous talents working together; the more he knows, the better and the more varied will he render experience. For instance, Butler's disparate images come from real learning (not from the author's subjective self), and consequently many of them combine without clashing (see $1: 212$ ). At the time that Johnson was reviewing staggering amounts of literary and scholarly material for quotations to use in his dictionary, he realized that "original genius" was rapidly becoming a catch phrase devoid of real value, and it was doubtless the total impression on him of the collective endeavor of so many scholars, poets, and writers - as contrasted with the current tendency to apply "original genius" to self-sufficient talent-that prompted his remark in Rambler 154 (written in the midst of the dictionary work), "The mental disease of the present generation, is impatience of study, contempt of the great masters of ancient wisdom, and a disposition to rely wholly upon unassisted genius and natural sagacity" (5:55).

Johnson was not advocating that writers base their works on allusions or that they compose in order to show off their learning. He simply meant that, if 
an author has studied others and has observed nature directly, his efforts will be better informed and will have the stamp of truth and experience. Reading them, we will immediately recall life itself, not other works of art or the writer's idiosyncrasies. ${ }^{7}$ It is by their attention to what is outside themselves that great authors at once are full of knowledge, transcend concern with self-expression, and become original. Originality to a large degree is already insured if the poet only turns to nature's "chaos of mingled purposes and casualties." But as Keast points out, Johnson saw that, since "some poets ... have elected to restrict themselves to a part of the diversified whole," the critic should not impose "a similar restriction on others." 8 Addison thus pleases Johnson because he "copies life with so much fidelity that he can be hardly said to invent, his exhibitions have an air so much original that it is difficult to suppose them not merely the product of imagination" (2:148). Real originality, and it is rare, grows from a detailed and encompassing awareness of fact and of the behavior and opinions of others. In Shakespeare, "The dialogue ... seems scarcely to claim the merit of fiction," says Johnson, because the plays contain "a vigilance of observation and accuracy of distinction which books and precepts cannot confer; from this almost all original and native excellence proceeds" (Preface to Shakespeare, 7:63, 88). Truth-not literal mindedness or realism, but truth from rendering experience in an imaginative, informed way-underpins good and lasting works. Johnson applies this to Virgil's Eclogues and concludes that the first and the tenth surpass the rest because "these two poems were produced by events that really happened; and may, therefore, be of use to prove, that we can always feel more than we can imagine, and that the most artful fiction must give way to truth" (Adventurer 92 $[2: 424]){ }^{9}$ But Johnson recognizes two real problems concerning the literary presentation of truth or morality. First, we become bored by repeated observations, pat phrases, and stock responses: truth degenerates into truism. Second, and at the other extreme, truth frequently lies beyond the realm of our own individual experience. It seems too exotic to accept, and we suspect it. The solution is to strike a balance of novelty and familiarity, to look for "the two most engaging powers of an author: new things are made familiar, and familiar things are made new" ("Pope," $3: 233$ ). Pope's Eloisa to Abelard is "so new and affecting that it supersedes invention, and imagination ranges at full liberty without straggling into scenes of fable" (ibid., p. 235). The novelty of a story can add power to its basis in truth. Both boredom and falsehood (or the suspicion of it) are replaced by an active interest close to life.

No writer can reach genuine originality solely through the use of new images. "Though nature itself, philosophically considered, be inexhaustible, yet its general effects on the eye and on the ear are uniform, and incapable of much variety of description" (Rambler 36 [3:197]). The original poet will focus with interest on

7/See Hagstrum's comments on Johnson's appreciation of Shakespeare as "a reading of life" (p. 179).

8/Keast, pp. 394-95.

9/Johnson was perhaps misinformed about the particular events described in the First Eclogue but was undoubtedly right about the personal nature of the poem. See Wendell Clausen, "On the Date of the First Eclogue," in Harvard Studies in Classical Philology, no. 76 (Cambridge, Mass., 1972), pp. 201-5. 
the activities and problems of human life and motivation. His observations and ideas stem from the continual novelty created by his thinking, philosophical approach to the shadowy labyrinth of experience. His poetry retains "its general power of gratifying every mind by recalling its own conceptions," while it engages the imagination with "new application of those views to moral purposes" (ibid.). Such an attitude helps to explain Johnson's liking for Eloisa to Abelard and his criticism of Paradise Lost for lack of familiar human interest. He was voicing an attitude about originality that became increasingly common in the transition to romantic aims and ideals, exemplified by Wordsworth's concentration on the inner life of the individual heart and mind. It is this deepening interest in the potentialities of the inner life for poetry that prompted Coleridge to claim that Wordsworth was "original." One major element in Wordsworth's originality, as Coleridge saw it, is that he was capable of producing "the first genuine philosophic poem." Similarly, Keats felt that the future path of originality-a philosophical exploration of the dark passages of experience, where "we see not the ballance of good and evil" - was henceforth the only course for poets to take: "To this point was Wordsworth come ... when he wrote 'Tintern Abbey' and it seems to me that his Genius is explorative of those dark Passages. Now if we live, and go on thinking, we too shall explore them." 10

Johnson was the first to say clearly that poetic originality no longer depended on the description of a previously unnoticed image or quality in the natural world. Originality now meant the ability to reflect the inner drama and process of a mind charged with feeling as it descries the value and the elusive truths of experience.

\section{Harvard University}

10/Coleridge, Biographia Literaria, ed. J. Shawcross (Oxford, 1907), 1:129; Letters of John Keats, ed. H. E. Rollins (Cambridge, Mass., 1958), $1: 280-81$. 